$\mathrm{Oz}$

Volume 25

Article 4

$1-1-2003$

Viejo House

Mathias Klotz

Follow this and additional works at: https://newprairiepress.org/oz

c) (i) $\Theta($

This work is licensed under a Creative Commons Attribution-Noncommercial-No Derivative Works 4.0 License.

Recommended Citation

Klotz, Mathias (2003) "Viejo House," Oz: Vol. 25. https://doi.org/10.4148/2378-5853.1381

This Article is brought to you for free and open access by New Prairie Press. It has been accepted for inclusion in Oz by an authorized administrator of New Prairie Press. For more information, please contact cads@k-state.edu. 


\section{Viejo House}

\section{Mathias Klotz}
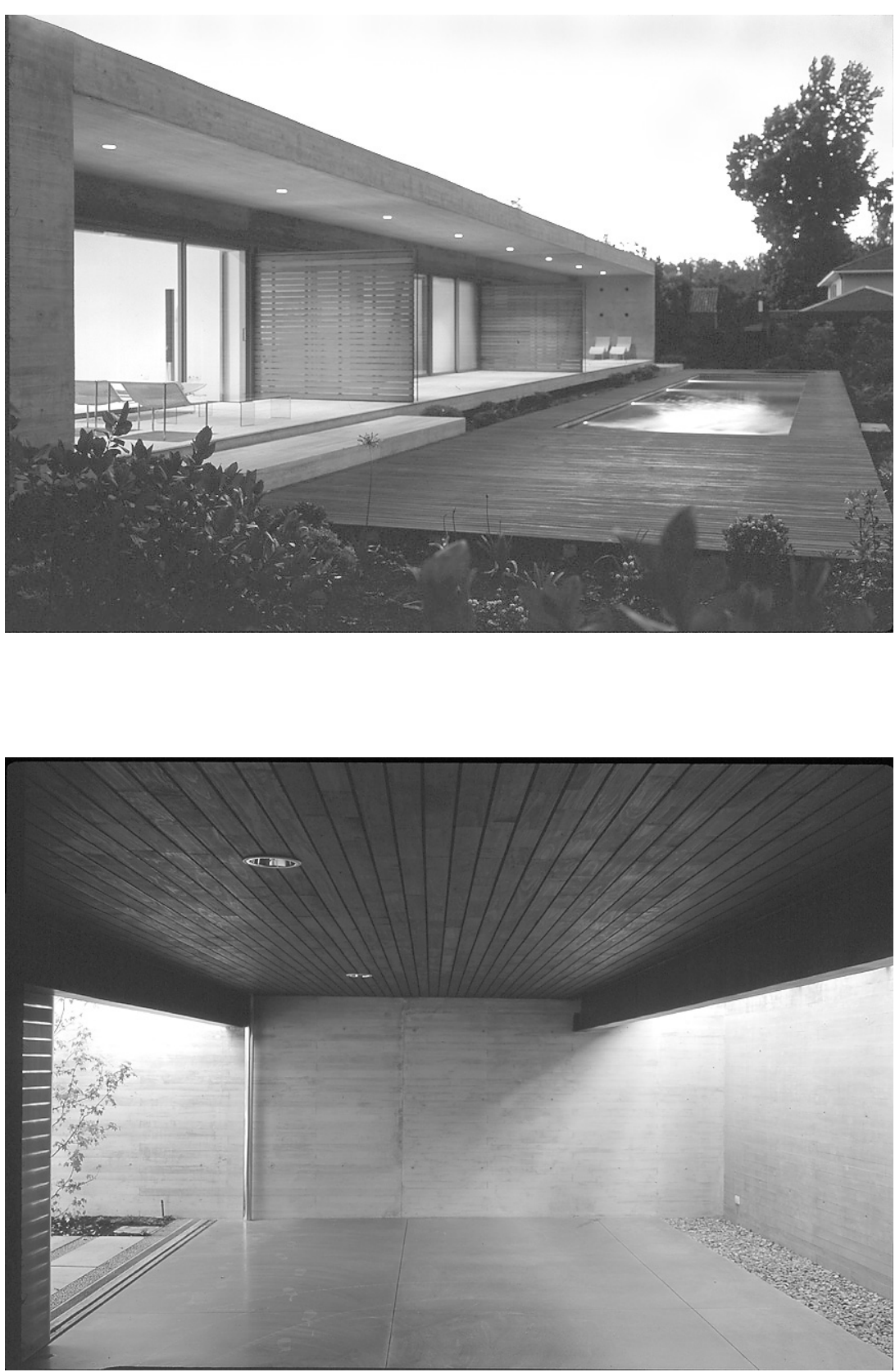

The Viejo Residence is a single-family house located in a Santigao neighborhood dating from the 1950s.

The original traditional-style residence was demolished. In its place we designed this new house that takes advantage of the original garden with its fantastic fifty-year-old trees.

The house is a one-story, twelve- by forty-meter rectangle built completely in reinforced concrete.

The program, typical for a family with two children, was organized by two corridors, one interior, the other exterior, that go from the front door, through the public and service spaces, to the more private areas.

The understated design resolves the constructive and programmatic problems simply, making use of differen textures on the exposed concrete as well as the different heights in the interior areas, depending on their use and proportion.

The roof of the house has been transformed into a terrace, taking advan tage of different planting heights and gaining 360-degree views of the hills surrounding Santiago.
La casa Viejo es una vivienda unifamiliar ubicada en un barrio residencial de Santiago, de la década de los 50 .

Originalmente existia una casa de estilo que fue demolida. En su lugar se proyecto esta otra que aprovecha el jardin original con fantásticos árboles de 50 años.

La casa es un rectángulo de 12 x 40 mts en un nivel, construido íntegramente en hormigón armado.

El programa, clásico de familia con 2 hijos, se organiza en base a 2 corredores, uno interior y otro exterior que avanzan desde el acceso, es decir, desde los programas más publicos y de servicio, hacia los mas privados.

Se trata de una obra tranquila que resuelve con sutilezas el problema constructivo y programático trabajando distintas texturas para el hormigón visto, así como también diferencias de altura al interior de los recintos, dependiendo de su uso y proporción.

La cubierta de la casa ha sido transformada en terraza, aprovechando esto cambios de nivel de las losas y ganando visas en 360 grados de los cerros que rodean la ciudad de Santiago. 


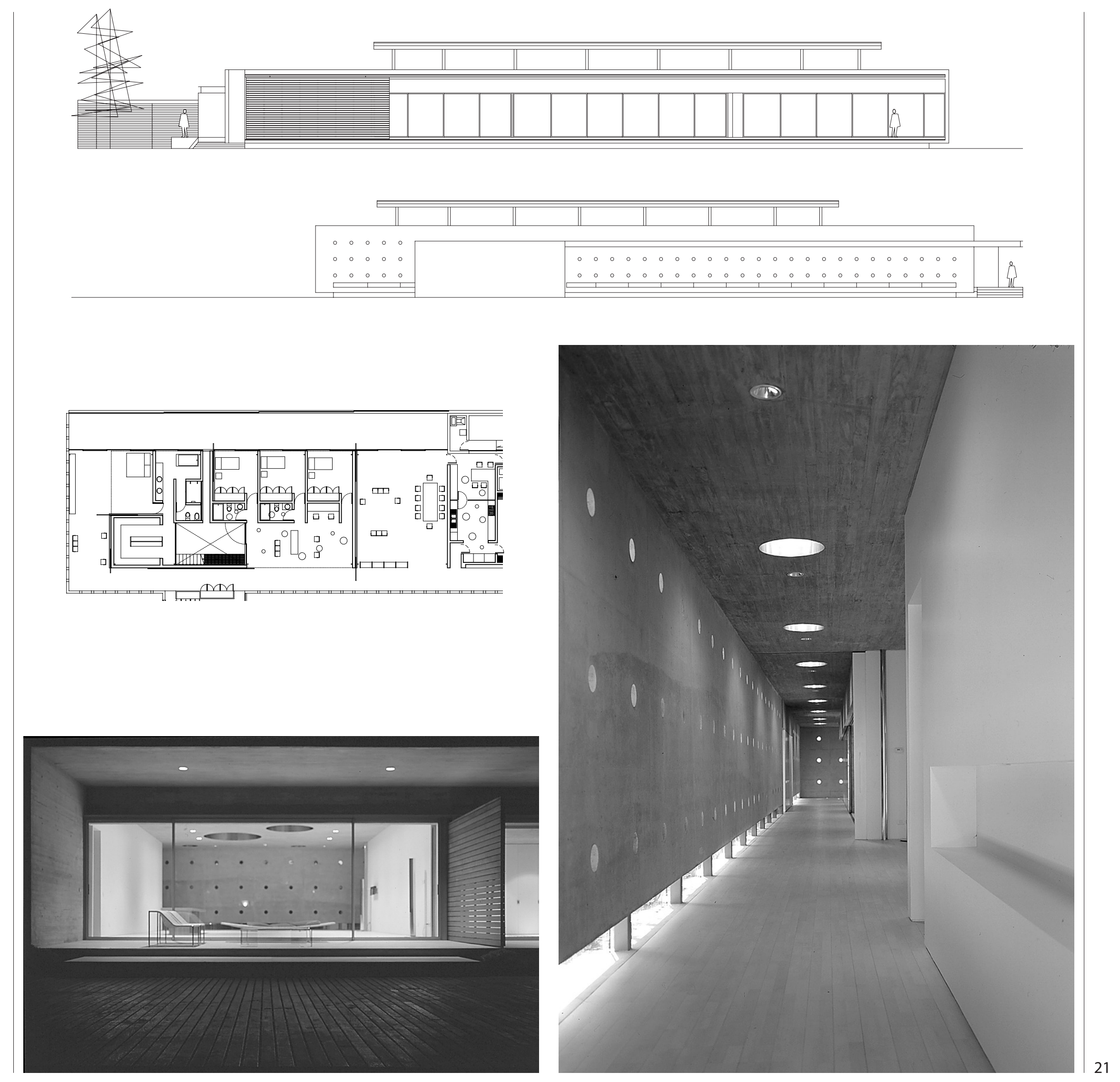

